This item is the archived peer-reviewed author-version of:

\title{
The construction of economic expertise
}

\section{Reference:}

Pelsmaekers Katja.- The construction of economic expertise Journal of multicultural discourses - ISSN 1744-7143 - Abingdon, Routledge journals, taylor \& francis Itd, 11:1(2016), p. 110-117 Full text (Publishers DOI): http://dx.doi.org/doi:10.1080/17447143.2015.1079205

To cite this reference: http://hdl.handle.net/10067/1284200151162165141 


\section{The construction of economic expertise}

Review article of “Economic Experts. A Discursive Political Economy of Economics" by Jens Maesse.

Abstract: this is a commentary article on "Economic Experts. A Discursive Political Economy of Economics". Referring extensively to a recent commentary by Joseph Stiglitz on the Greek referendum ( 5 July 2015) in The Guardian, I investigate and illustrate the theoretical approach put forward by Jens Maesse. Drawing on empirical studies in journalism, sociology and management I argue for a more empirical specification of the model, including a detailed study of discourse transformations as experts move between epistemic fields, as well as a reconsideration of the power structure between expert and client or user.

Keywords: expert discourse, media, managerialism, neo-liberalism

\section{Star economists}

In "Economic Experts", Jens Maesse explains and theorizes phenomena that we are able to witness almost daily now: star economists are giving us expert opinions on public events and projects, and seem to gather more star quality in the process. In addition, Maesse presents a methodology that should allow us to study these phenomena more closely and help us to explain what "construction" means in relation to "economic expert". His main point is that an "economic expert" is a heterogeneous construct made possible by power conversion from one field to another through discursive positioning processes. In my review, I will use specific examples to examine the Discursive Political Economy of Economics model and add a question mark here and there.

In the very recent political upheaval over the Greek debt crisis and Greece's membership within the Eurozone - the group of European countries that adopted a common currency, the euro, and promised to coordinate their fiscal and economic policies - we have seen once again how much the mediatized public discussion was dominated by a small group of star economists. Of course, it could be argued that the whole question was a truly economic question in which many of the economic specialist fields came into play: monetary and fiscal policy, economic growth, labor economics, international trade and so forth. In order for journalists to be able to get a grasp on the subject matter, expert explanations are not only handy but even necessary. However, what we saw was that economic experts handed out opinions on political decision-making by government and electorate, while the economic perspective sometimes receded into the background.

With reference to the bailout referendum organized by the Greek government for the people of Greece on 5 July 2015, the 'progressive' British newspaper The Guardian published a piece entitled "Greek referendum: how would top economists vote?"' The newspaper collected previously published commentaries by a small group of famous economists, including 'usual suspects' Joseph Stiglitz, Paul Krugman and Thomas Piketty, followed by another small group of title-laden individuals, and ending with a category called "Professors of economics at Greek universities", referring to an open letter endorsed by 246 Greek academics the day before. 
Next to each individual economist's name and credentials (e.g. "Nobel laureate in economics and professor at Columbia University") a capitalized "NO" or "YES" was linked to their name, according to the economists' putative answer to the hypothetical question "how would you vote in the referendum?" In the case of Stiglitz, for instance, The Guardian partly re-published an earlier piece of his that appeared in the newspaper on June 29, in which the Nobel laureate ends somewhat cautiously:

\begin{abstract}
"It is hard to advise Greeks how to vote on 5 July. Neither alternative - approval or rejection of the troika's terms - will be easy, and both carry huge risks. A yes vote would mean depression almost without end. Perhaps a depleted country - one that has sold off all of its assets, and whose bright young people have emigrated - might finally get debt forgiveness; perhaps, having shrivelled into a middle-income economy, Greece might finally be able to get assistance from the World Bank. All of this might happen in the next decade, or perhaps in the decade after that.

By contrast, a no vote would at least open the possibility that Greece, with its strong democratic tradition, might grasp its destiny in its own hands. Greeks might gain the opportunity to shape a future that, though perhaps not as prosperous as the past, is far more hopeful than the unconscionable torture of the present.
\end{abstract}

I know how I would vote." ${ }_{\text {ii }}$

On July 3 The Guardian boldly concludes that "it is clear the Nobel laureate himself would vote no" and backs that up with a fraction of the quote higher: "A no vote would at least open the possibility that Greece, with its strong democratic tradition, might grasp its destiny in its own hands. Greeks might gain the opportunity to shape a future that, though perhaps not as prosperous as the past, is far more hopeful than the unconscionable torture of the present".

This is an interesting case in several ways and clearly illustrates some of the points made by Jens Maesse. First of all, Stiglitz is clearly positioned in the newspaper as someone with the highest qualifications in his academic field ("Nobel laureate"). Yet as a US citizen and economist he gives his opinion on matters that are not strictly economics, but rather concern a political question for the citizens of Greece to decide. Greece is heavily indebted and while the country has been on the brink of bankruptcy several times, the question politicians and citizens have been debating is how the situation had best be approached, and which measures would be most feasible and least likely to make the situation even worse. The referendum, which was to be held on July 5 2015, was meant for Greek voters to decide whether they supported Prime minister Tsipras' view that even more austerity without debt restructuring as proposed by the European Commission would be unbearable ("no"), or whether the European Commission's conditions for further austerity measures in exchange for more financial aid should be accepted without further ado ("yes").

The question "how would you vote" does not only fall outside Stiglitz' academic field, but is also highly speculative and counter-factual. As a US citizen, Stiglitz is in no position to vote in this question, even if he wanted to. Moreover, whatever the outcome of the vote, he was never going to have to suffer the consequences either. That may in part explain why his final 
answer remains cautiously implicit in the June 29 article ("I know how I would vote"), 'translated' by The Guardian in the July 3 article as a "no". The main argument for the putative "no" vote, moreover, is not an economic one, but one of political sovereignty: neither policy decision will be easy or even satisfactory, he writes, but a no-vote "might" at least offer the Greeks an opportunity to seize their own destiny, as is in their democratic tradition. Not only does this reference to tradition and history conveniently cloak various non-democratic episodes and institutions in Greek history (hence supporting the Greek reader or sympathizer in a moment of distress), but the argument itself is admittedly vague and analogical. In other words, this is not academic discourse in the field of economics. By being given the floor in this debate on the merit of his elite academic position, Stiglitz has (once again) been able to convert his academic power into media power; not only that, by voicing his opinion (which was reproduced in the same newspaper again a few days later, and in many other media as well), he was able to exchange power and credibility with those who believed that a no-vote was politically opportune. Clearly also, this means that in doing so, Stiglitz no longer acted and spoke according to the rules of his discipline, in spite of the fact that it is his discipline (as well as credentials gained through his former position in the World Bank and other such institutions) that gives him the authority to speak in the media in the first place. In his media role, he is able to engage in speculation, and to utter (positive) stereotyping and subjective hypothetical statements. Stiglitz, of course, is aware of his hybrid identity as a newspaper commentator and economist, and is aware of the different roles and rules that apply in media and academia. The carefully implicit "I know how I would vote" is elegantly private enough for such a subjective statement not be offensively unscientific or offensively politically biased. From a media point of view, however, the statement was obviously not clear enough yet and was translated into "clearly no" by Katie Allen in the July 3 article.

\section{Expertise as (re) production industry}

That this is not a unique example of academic capital converted into media capital is more than clear in this context too; apart from the other names mentioned higher, we find an entire industry, as it were, operating globally, facilitating this kind of conversion. Stiglitz' contribution of June 29, for instance, appeared by virtue of Project Syndicate. This is an organization that has mediated for more than two decades between knowledge elites, "those who are shaping the world's economics, politics, science and culture" and the written media. They describe their mission as

"render[ing] complicated ideas in a language that educated readers everywhere can use to make informed choices, while providing a platform for the world's foremost statesmen, policymakers, intellectuals, and activists to reach a global audience without public relations and political hype." iii

The stated aim is clearly to influence action outside the realm of the media, by providing "language" that people can "use" to make decisions. It is probably no coincidence that "use" here reads as meaning 'understand' as well as 'reproduce'. Note also the somewhat negative term "complicated" (vs. complex) which they suggested is improved into a format 
usable for spreading. However, these ideas might well lose something (and gain something else) on the way. As Maesse writes:

" Furthermore, ideas and concepts from the world of economics must be translated into the world of politics and the economy, they circulate from one field to another by interpretive appropriation and usage. Thereby they change their meaning, their status and their role according to the social rules in the respective social worlds" (p. 6).

Notable, also, is the reach of Project Syndicate, at least in their own words: 500 newspapers and other publications, 154 countries, 300 million readers. Newspapers can "secure rights" to a particular series of opinions and "visionary" comments according to their editorial needs.

However, why would newspapers want or need expert opinions to fill their columns and pages? Why do they not just report news as it happens? Because, say journalism scholars, after 1960 purely descriptive reporting gradually receded in favor of interpretive reporting (Albaek 2011: 326). In descriptive reporting journalists were relying on authoritative sources to decide what was newsworthy. The authoritativeness of such a source was furthermore linked to his or her hierarchical position in politics (Albaek 2011: 325). Here Maesse points to Habermas and Jameson, and their observation that globalization changed the institutionalized framework in such a way that a "lag of legitimacy" was created, which was gradually filled by a "dialectics of academization and elitism" in response to a "social legitimacy demand from media, politics and business firms" (Maesse p.11). "Globalization" is of course a cover term for many different phenomena, and Albaek (2011) sees more specific factors contributing to the neediness of the media for new authoritative voices. With the advent and success of television and later the internet, descriptive reporting no longer made sense, as viewers could already see or access what was happening on their screens. Especially print journalism, therefore, felt the need to secure its own niche in the news market and became more interpretative, attempting to explain why things were happening as well as what was happening. After the Watergate scandal, journalists also felt that politicians could no longer be trusted and a 'political logic' was gradually replaced by a 'media logic', i.e. journalists took more control of the news production. Then, faced with an increased number of sources on the one hand and a conventional journalistic ideology of objectivity on the other, they needed "compensatory legitimation" (Weiler 1983, cited in Albaek 2011), and needed to "draw on the authority of experts, persons who are perceived as having neutral, factual knowledge and as not being part of the conflict" (Albaek 2011: 328). Since stories now had to be developed in greater depth, consultation with experts also became more desirable to be able to move beyond simplistic or inaccurate analyses. In Albaek's (2011) empirical study of the use of experts in election coverage, another interesting finding emerges. Why is the group of experts cited or used in print media such a relatively small circle? Is it, as suggested by Maesse, the amount of capital gathered in the "dialectic of academization and elitism" that is driving the media to give the floor to an expert, which is necessarily limited to a small circle? It probably is, at least partly so. But there may be other, more mundane factors, such as availability. Not only stars but especially lower-ranked academic staff may be more eager to talk to journalists or write for them - 
because it gives them the visibility they crave more than their more illustrious colleagues. In metaphorical terms, the marginal return might be higher for aspiring climbers. The rationale for lower-ranked academics to be in the press is not just power and influence in other social fields, but primarily to gain influence in their own fields. There is definitely realism in Maesse's idea that capital generated from other fields than academia can also be converted back to academia - albeit to a limited extent. Albaek mentions another factor for the reappearance of the same group of experts time and again. This is habit, or ease, or in his own words: "a Matthew effect comes into play: researchers who have been used extensively by journalists in the past are simply used further" (2011: 340). With respect to Maesse's analysis, however, it is not clear whether this kind of inertia is also explained by his theory.

Finally, media experts agree that the media's need of (other) experts has grown explosively, and not only in the print press but throughout. As a result, two other kinds of so-called 'experts' have emerged. Rafter (2014), writing about the role of media elites in the interpretation of the Irish banking crisis, mentions two other categories of "pundits" that became relevant in the wake of the 2008 financial crisis. What is interesting about them is that they might well be subversive actors in a field assumed to be dominated by academic power. Rafter mentions "celebrity pundits" who are less defined by their specialist expertise in a particular field such as economics or finance, but who are useful in the 'media logic', especially in a competitive news market. They are able to attract audiences through their ability to engage in speculation and conjecture, and know how to make provocative statements in no uncertain terms. Another interesting category is the "journalist-expert", a kind of 'own brand' pseudo expert helping audiences with the intricacies and difficult language that is often associated with economic and business news (Rafter 2014: 600). In a competitive news market where time is money and objectivity is secondary to viewing rates, these 'own brand' experts might well take up part of the academic expert's sphere of influence and somewhat undercut the mechanism described by Maesse.

\section{Hegemonization and the re-emergence of "universal experts"?}

Maesse states that economic experts hegemonize their interpretations, and that this hegemonic claim is made against other, alternative forms of knowledge. It is difficult to deny that economic, and particularly neo-liberal perspectives have come to encroach upon most other social fields, including language (e.g. Heller 2010). In that most general sense, it could be argued that the economic perspective has become hegemonic in the western public sphere, and that this is a self-reinforcing process. Because the economic perspective is dominant, economic experts tend to be asked more frequently than, say, medical experts or natural science experts to offer their highly-valued knowledge in areas beyond the scope of their academic expertise. In that way, the (broadly neo-liberal) economic perspective (discourse, ideology) is reinforced all the time and the more this happens, the more actors in other fields may feel the need to legitimize their own actions (in whichever 'logic' they operate) by drawing on support from the elite club of economic experts. As a result, the number of fields in which economic experts have influence grows, well beyond business, politics and the media. 'Managerialism' as culture has been documented in many social 
fields, including fine arts, medical care and not least education. But where is the source of this spiral? Do we set so much store by economic experts because they have been certified by the "dialectic of academization and elitism" (Maesse) or because they are assumed special knowledge in a field which is deemed to be more fundamental to society than any other field? Medical experts and natural science experts go through much the same academic mills of elitism, but their power and influence in media, business and politics seems much smaller and less relevant. And does that mean that economic expertise is gaining a kind of monopoly position in western society (and beyond)? In The Social Construction of Reality Berger \& Luckmann (1966) saw a contrast between monopolistic "universal experts" of traditional societies, who are the source of special and privileged knowledge in every field, and experts competing in a modern pluralistic society. They ask the question how lay people or 'novices' judge expertise without having the expertise they are judging. The effectiveness of strategies to judge expertise is dependent, they say, on the details of the social process governing the sort of expertise in question. In some social processes, there is a "tight feedback loop between the experts' claims" (Koppl 2010:221) and lay people's experience, which makes this judgment easier. A weather man's expertise in predicting the weather seems a good case in point. In case this feedback loop is not so tight, rating agencies may take it upon them to replace the lay judgment of outcomes. Basically, this is also what happens in academia: individuals, departments and schools are rated continuously and rankings are made based on excellence. But is that the true source of capital for economic experts, as Maesse suggests? Or have we arrived at a situation where economic experts claim special knowledge that applies to almost everything else in society, which in fact makes their "special knowledge" independent of any empirical control or reasoned judgement beyond themselves? By the same token, power in public debates may reside more in the individual's ability to display some socialization with economic language use and his or her ability to 'translate' that (as in the case of Rafter's pseudo experts) than by positioning themselves with titles and rankings which might seem esoteric to lay people anyway.

\section{The empirical return}

Let us now return to Joseph Stiglitz for an instance. In Maesse's model, this is a good example of an expert who has been able to capitalize, through sustained conversion between academic, media and political fields at least, on the credentials bestowed upon him in the academic elite system. He has thus been able to accumulate (discursive, real) power in these and possibly other areas of public life. But in those social processes, what does it mean for an actor to figure as an expert? 'Expert' is a term mostly reserved for relative outsiders, or at any rate, the special knowledge that the expert has typically derives from a field other than the one he or she is called upon to serve. A forensic expert serves in court, an economic expert serves in politics or the media. Inside their own disciplines, these people are peers (or leaders), but outside their discipline they are experts. Note the word "serve". How does the role of expert in a given field figure next to that of leader, manager or decision-maker in the field he or she provides his or her expertise with? Expert discourse seems to be re-appropriated by (other) powerful actors in the field or situation that calls for expert knowledge or opinion. The expert is given the floor, is allowed to contribute and 
rewarded directly or indirectly accordingly, but seldom takes over the game entirely. This seems to be true even when they occupy a fairly monopolistic position institutionally (cf. forensic scientists in the US, cf. Koppl 2010), or when they approach the status of "universal expert" by virtue of their field of expertise. Managers, newsmakers and politicians who are giving the floor to economic experts may gain and give the expert more credibility, but seem to want to serve their own purposes of power gain through information or legitimation first. In a business organization, for instance, field experts or consultants are often called in to confirm or legitimize managerial decisions or designs already taken (cf. Sturdy 1997). Similarly, The Guardian may have conveniently used Stiglitz, known for his critical stance on globalization and high finance, to underline their (own) credibility as news interpreters and commentators on the left side of the ideological spectrum. Stiglitz provided his name, and therefore high-profile "no" text to support The Guardian's criticism of the political and economic establishment represented by the European Commission, creators and advocates of the "yes" option in the Greek referendum.

Whereas there is an undeniable hegemonizing effect of broadly neo-liberal and simplified economic perspectives on many walks of life, this does not mean that individual experts are able to hegemonize their views. One of the reasons might be that within a more global and hegemonized discourse of market-driven economics in many different fields, experts of somewhat competing views within that paradigm now have a hard time to adapt their discourse in such a way that they can also persuade or influence outsiders or lay people. One of the frequently heard popular comments in the Greek referendum was that the "yes" vote and the "no" vote options were difficult to distinguish in terms of content and projected impact. Sophisticated differences may be difficult to 'dumb down' enough so that novices will also understand. That may be one of the reasons why Stiglitz, in his Project Syndicate piece, had to resort to common sense concepts like democracy and sovereignty. Attractive as Maesse's model and methodology appears, I fear that for a good understanding of the discursive political economy of economics many "details of the social process" (Koppl 2010) may need to be studied more empirically, including a close study of discursive transformations as actors move between knowledge fields. Also, the curious relation between expert and users of expertise may need to be explored further. The suggested symmetry, finally, in the representation of the trans-epistemic field (figures 1 and 2) and in the relations between capital production, conversion and discursive polyphony seems, for several reasons named higher, somewhat unrealistic and calls for closer scrutiny of real empirical material. More empirical substance and possible modifications accordingly would only make this theory richer and more powerful.

\section{References}

Albæk, E. (2011). The interaction between experts and journalists in news journalism. Journalism, 12(3), 335-348. Berger, P. \& T. Luckmann (1966). The social construction of reality. New York, Anchor Books. Heller, M (2010). The Commodification of Language. Annual Review of Anthropology. 39: 101-114 Koppl, R. (2010). The social construction of expertise. Society 47 (3) 220-26. 
Rafter, K (2014). Voices in the crisis: the role of media elites in interpreting Ireland's banking collapse. European Journal of Communication 29(5), 598-607.

Sturdy, A. (1997). The consultancy process -- an insecure business? Journal of management studies 34(3) 384-413. Weiler, H.N. (1983). Legalization, expertise and participation: strategies of compensatory legitimation in educational policy. Comparative Education Review 27: 259-77

' The Greek referendum: how would top economists vote? The Guardian, 3 July (http://www.theguardian.com/world/2015/jul/03/greek-referendum-what-the-experts-say)

ii Joseph Stiglitz: how I would vote in the Greek referendum. The Guardian, 29 June (http://www.theguardian.com/business/2015/jun/29/joseph-stiglitz-how-i-would-vote-in-the-greek-referendum) iii http://www.project-syndicate.org/about\#AXR23X4XXLoP6J16.99 